\title{
Biochemistry and Physiology of Gastrointestinal Somatostatin
}

\author{
MICHAEL R. LUCEY and TADATAKA YAMADA
}

\begin{abstract}
Somatostatin, a tetradecapeptide initially isolated from the ovine hypothalamus, is widely distributed throughout the gastrointestinal tract where it may act as a hormone, local chemical messenger, or neurotransmitter to elicit many physiological actions. Release of somatostatin from $D$ cells in the gut is regulated by mechanisms that are both dependent on and independent of cAMP. In most cases somatostatin acts to inhibit the function of its target cells. It performs this action in part via pertussis-toxin-sensitive inhibitory guanine nucleotide-binding proteins that regulate adenylate cyclase activity. Other mechanisms may involve sites of action distal to intracellular second messenger systems.
\end{abstract}

KEY WORDS: somatostatin; gastrointestinal tract.

The story of the discovery and isolation of somatostatin is one in which an unexpected and unexplained observation was pursued with great application to yield novel and far-reaching results. In 1968 , while searching for an hypothalamic growth hormone releasing factor, Krulich et al (1) found that fractions obtained on chromatography of sheep or rat hypothalamus had the effect of inhibiting growth hormone release from rat anterior pituitary. Subsequently, investigators in Guillemin's laboratory made a similar observation, and they set out to identify the cause of this phenomenon. In the course of their labors they isolated from 500,000 sheep hypothalami, a peptide we now call somatostatin-14 (S14), and by stepwise Edman degradation they determined its structure $(2,3)$. They described a 14-amino acid peptide with a cyclic conformation maintained by an intramolecular disulfide bond linking two cysteine residues (Figure 1).

\footnotetext{
Manuscript received March8, 1988;accepted November 14, 1988. From the Department of Internal Medicine, University of Michigan Medical Center, Ann Arbor, Michigan 48109-0362.

This work was supported by NIH grant R01DK33500 and funds from the Michigan Gastrointestinal Peptide Research Center (NIH grant P30DK34933).

Address for reprint requests: Tadataka Yamada, 3912 Taubman Center, University of Michigan Medical Center, Ann Arbor, Michigan 48109-0362.
}

This peptide inhibited release of growth hormone from somatotrophs. Following this advance, many other inhibitory actions of somatostatin were described. In 1975, Arimura et al $(4,5)$ described the first radioimmunoassay for somatostatin and, thereafter the widespread distribution of somatostatin both within mammalian tissues and throughout the phylogena became clear. Somatostatin is present in virtually every tissue in the mammalian body, in all classes of vertebrate, in protochordate plants, protozoa, and even prokaryotes. Four interrelated functions have been proposed for somatostatin in man-that of neurohumoral regulator, neurotransmitter, endocrine hormone, and paracrine hormone.

This review will outline current understanding of the biochemistry, tissue distribution, release, and physiological function of gastrointestinal somatostatin and place particular emphasis on recent advances concerning the cellular aspects of release and mechanism of action of somatostatin.

\section{STRUCTURE AND BIOSYNTHESIS}

Since its initial purification, somatostatin-14 (S14) has been isolated and its amino acid sequence determined from a variety of species and tissues 


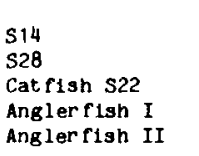

\begin{tabular}{lllllllllllllllllllllllllllll}
1 & 2 & 3 & 4 & 5 & 6 & 7 & 8 & 9 & 10 & 11 & 12 & 13 & 14 & 15 & 16 & 17 & 18 & 19 & 20 & 21 & 22 & 23 & 24 & 25 & 26 & 27 & 28 \\
\hline
\end{tabular}

Ala Gly Cys Lys Asn Phe Phe Trp Lys Thr Phe Thr Ser Cys Ser Ala Asn Ser Asn Pro Ala Met Ala Pro Arg Glu Arg Lys Ala Gly Cys Lys Asn Phe Phe Trp Lys Thr Phe Thr Ser Cys Asp Asn Thr Val Thr Ser Lys Pro Leu Asn Cys Met Asn Tyr Phe Trp Lys Ser Arg Thr Ala Cys Ala Ala Ser Gly Gly Pro Leu Leu Ala Pro Arg Glu Arg Lys Ala Gly Cys Lys Asn Phe Phe Trp Lys Thr Phe Thr Ser Cys Ser Val Asp Ser Thr Asn Asn Leu Pro Pro Arg Glu Arg Lys Ala Gly Cys Lys Asn Phe Tyr Trp Lys Gly Phe Thr Ser Cys

Fig 1. Amino acid sequences of somatostatins (from reference 66). including porcine hypothalamus (6), anglerfish pancreatic islets (7), guinea pig stomach and pancreas (8), catfish pancreas (9), and frog brain (10). Although when amino acid sequences are deduced from cloned mRNA in some species the possibility of variability in the $\mathrm{S} 14$ amino acid sequence has been raised, in fact all S14 identified to date have been identical to that originally described. This represents a remarkable degree of phylogenetic preservation.

In 1978, Pradayrol et al (11) reported the purification and sequencing of a larger somatostatin isolated from porcine intestine. It consisted of 28 amino acids ( $\mathrm{S} 28$ ) and contained the S14 moiety at its carboxyl terminus linked to the first 12 amino acids by an Arg-Lys dipeptide (Figure 1). Subsequent studies have shown that $\mathrm{S} 28$, in contrast to $\mathrm{S} 14$, can have considerable interspecies variation, especially when isolated from fish. S28 exerts many actions when administered in vivo and in vitro. While these are frequently of a similar nature to those of S14, there are considerable differences between the two moieties in specific actions, po- tency, and metabolism (see below). The relative importance of S14 and S28 as physiological effectors remains a subject of debate.

By application of recombinant DNA technology, larger precursor forms of somatostatin comprising more than 100 amino acids have been discovered. These have been called preprosomatostatins. cDNAs encoding anglerfish (12), catfish (13), rat (14), and human preprosomatostatin (15) have been isolated and cloned. In each case S28 is found to occupy the carboxyl terminus. The presence of multiple mRNAs encoding somatostatin in anglerfish and catfish pancreata is of particular interest, indicating that in submammalian species there may be expression of different genes for somatostatin within the same organ. The structural genes for human $(16)$ and rat $(17,18)$ somatostatin have been cloned and are quite similar in overall conformation.

Figure 2 describes some of the possible routes for posttranslational processing of somatostatin precursors to S28 and S14. It is uncertain whether in mammals S28 is formed first and then cleaved to

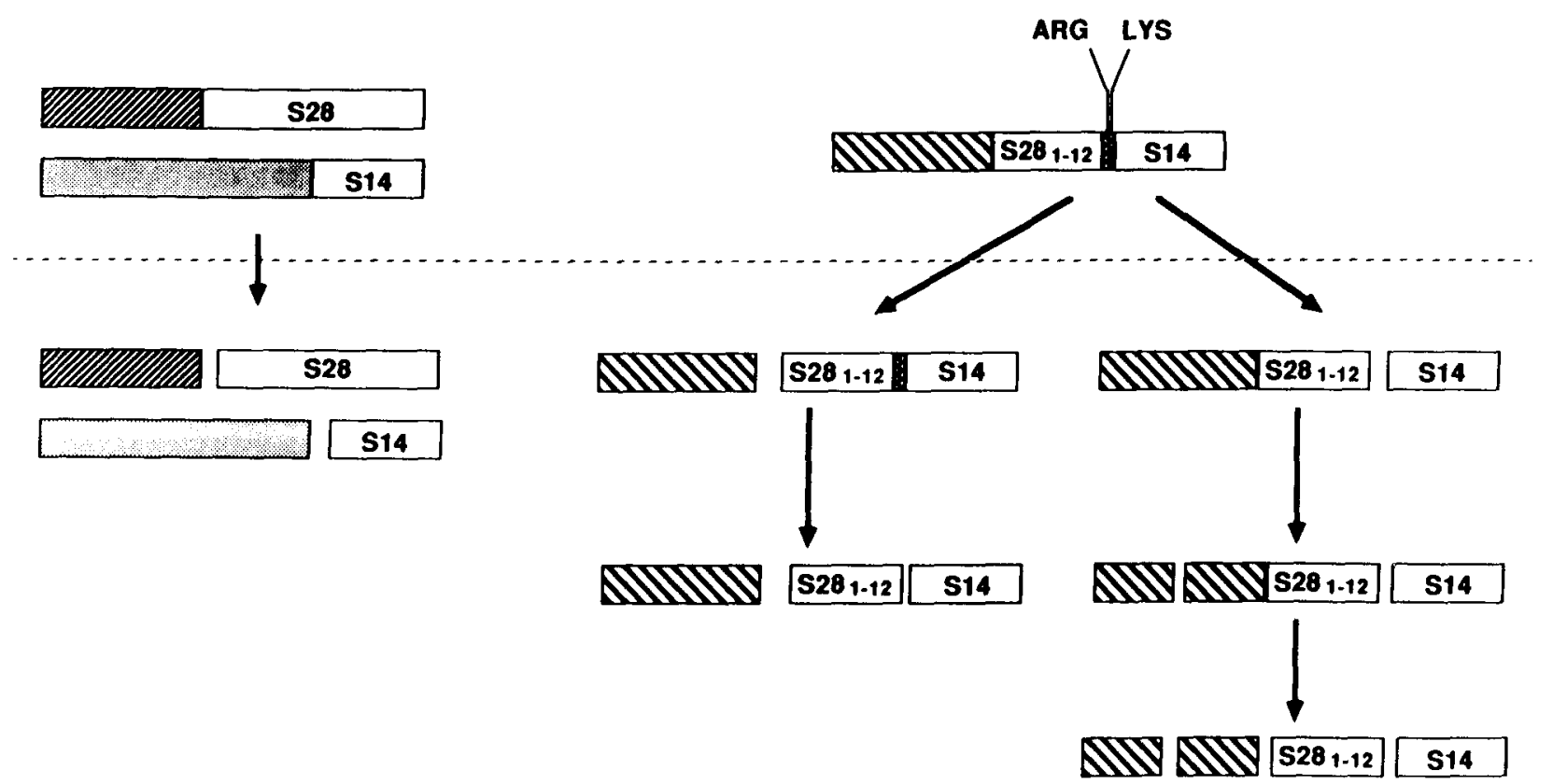

Fig 2. Alternative mechanisms for preprosomatostatin posttranslational processing (from reference 66). 
S14 and a remnant peptide $\left(28_{12}\right)$ or whether S28 and S14 are each derived directly from larger precursors. Not only is intraspecies variation in posttranslational processing likely, but also within the same species, different tissues may process somatostatin precursors differently. This conclusion is strongly supported by the striking differences in distribution of S14 and S28 throughout the mammalian gastrointestinal tract (see below).

\section{TISSUE DISTRIBUTION}

As stated above, somatostatin is almost ubiquitous in the mammalian body. The gastrointestinal tract and pancreas contain the greatest amounts of somatostatin. The majority of somatostatin in the human gut is confined to the mucosal layer where it is localized in endocrine cells, termed D cells. The remainder is present in neural cells, in which it forms part of the peptidergic neural system. In the stomach there are important differences between the D cells of the fundus and those of the antrum. Fundic D cells are of a "closed type," with no obvious luminal contacts; antral D cells are of an "open type," with their apical membrane exposed to the gastric lumen (19). As a consequence, it has been suggested that antral $\mathrm{D}$ cells respond to luminal stimuli, whereas fundic D cells do not. Both fundic and antral D cells possess long cytoplasmic extensions that appear to abut on effector cellsparietal and chief cells in the fundus, gastrin cells in the antrum (20-22). The presence of these cytoplasmic extensions has been interpreted as evidence for a local or paracrine route of action for somatostatin.

Duodenal D cells are typical flasklike endocrine cells with their apical membranes open to the intestinal lumen (21). In jejunum and ileum, somatostatin is located most commonly in neurons $(23,24)$. There is little somatostatin in the colon.

S14 is the predominant molecular form of somatostatin in the stomach, duodenum, and pancreas of rat and man (24-28). There is an increase in the relative proportion of $\mathrm{S} 28$ in the remainder of the small intestine.

\section{METABOLISM}

The half-life of S14 in plasma is extremely short, ranging from 0.5 to $3.0 \mathrm{~min}(29-35)$. In contrast, the plasma half-life of S28 has been found consistently to be two to five times longer $(31,33,35)$. These results have led to confusion in estimating the relative potency of the two moieties. Many sites for degradation of somatostatin have been proposed, including liver $(36,37)$, pancreas (38), lungs (39), and kidneys (40). Recent studies have demonstrated rapid degradation of somatostatin by capillary aminopeptidases on isolated bovine brain microvessels (42) and also by aminopeptidase and endopeptidase activity on plasma membrane vesicles prepared from pig small intestine cells (42). These observations provide a potential explanation for rapid metabolism of endogenous somatostatin released by brain neurotransmissions or from gut mucosa. The possibility of capillary peptidase activity in vessels outside the brain has not been studied.

\section{REGULATION OF SOMATOSTATIN RELEASE}

Elucidation of the mechanisms by which release of somatostatin is regulated has been confounded by a multitude of problems. When studied in vivo, measurement of somatostatin in plasma has posed many difficulties. Circulating plasma somatostatin is collected distant from the site of release and probably represents a mixture of somatostatin released from many sources rather than from a single site. Conversely, since somatostatin is such an evanescent peptide and since it may be released for a paracrine action, circulating levels may remain unchanged in spite of significant local release. One response to these considerations is to study somatostatin release in an isolated organ preparation. However, even in such a system there may be regional variations in release within the organ or other uncontrolled and conflicting influences. Consequently isolated cellular preparations have proved particularly useful in elucidating both the intricate balance of controls that order somatostatin release and the intracellular mechanisms by which these controls are exercised.

Table 1 lists some of the factors shown to influence gastrointestinal somatostatin release in various models. Somatostatin release in response to luminal stimuli is of particular interest. Many studies in animals and man have shown that luminal nutrients, fat, and protein in particular, almost invariably release somatostatin into portal blood or peripheral circulation (43-47). Both S14 and S28 are released. The sites of release are probably gastric and duodenal, while in the intact dog at least the pancreas does not appear to contribute (48). The mechanisms by which nutrients initiate or sustain somatostatin release have not been elucidated well. 
Table 1. Summary of Agents that Influence Gastric SOMATOSTATIN RELEASE*

\begin{tabular}{ll}
\hline \multicolumn{1}{c}{ Stimulants } & \multicolumn{1}{c}{ Inhibitors } \\
\hline Luminal factors & \\
HCl & $\mathrm{NaHCO}_{3}$ \\
Mechanical & Peptone \\
Casein & \\
Fat & \\
Glucose & \\
Circulating nutrients & \\
Free fatty acid & \\
Peptides & Substance P \\
Glucagon & Met-enkephalin \\
Secretin & Dermorphin \\
VIP & Insulin \\
GIP & PP \\
Calcitonin & GRP \\
CGRP & \\
Gastrin & \\
CCK & \\
Bombesin & \\
Neurotransmitters and amines & Acetylcholine \\
Epinephrine & GABA \\
Norepinephrine & Serotonin \\
Dopamine & \\
Nucleotides and prostaglandins & \\
Cyclic AMP & \\
Prostaglandin E & \\
Drugs & \\
Theophylline & \\
Tolbutamine & \\
TPA & \\
Diacylglyceride & \\
Dimethyl-phenyliperazinium & \\
\hline From reference 66. & \\
\hline
\end{tabular}

*From reference 66.

One possibility is that nutrients stimulate acid secretion, which in turn stimulates somatostatin release. Since somatostatin may act as an inhibitor of acid secretion, this would constitute a negativefeedback loop. However, although acid in many circumstances can stimulate somatostatin secretion $(49,50)$, this is not invariable (51). Since neutral solutions of nutrients can stimulate somatostatin release in antrectomized dogs (43), it is likely that nutrients can stimulate somatostatin independently of acid secretion. Thus the physiological importance of luminal acidity in somatostatin release is uncertain.

Somatostatin release stimulated by luminal nutrients is under neural control. However, in vivo and in vitro studies directed at defining these neural influences have yielded conflicting results. For example, in man and in intact dogs $(52,53)$, vagal tone appears to facilitate somatostatin secretion, while in intact cats (54), in isolated stomach, and isolated pancreas preparations cholinergic agonists are inhibitory (55-58). Similar conflicts are found with other neuropharmacologic agonists and antagonists.

Studies using an isolated cell culture system have allowed careful dissection of some of these influences. This technique achieves an enriched primary culture of somatostatin cells derived from canine fundic mucosal cells $(59,60)$. Canine fundic mucosal cells are dispersed with collagenase and then separated with counterflow elutriation. Following this process, somatostatin cells comprise about $9 \%$ of total cells in the small cell fractions and are separated completely from parietal cells and partially from chief and mucosa cells. Mast cells and other endocrine cells are also present. These small cell fractions are then plated onto collagen and maintained in primary culture for two days, after which somatostatin cells comprise $70 \pm 6 \%$ of cultured cells. These cells can then be subjected to short-term incubation with neuropharmacologic agents and somatostatin release estimated.

Using this primary culture of enriched canine fundic D cells, at least two stimulatory pathways for somatostatin have been defined (59-63): a cAMPdependent system and a cAMP-independent system (Figure 3). The cAMP-independent pathway may involve membrane phosphoinositide turnover and/ or intracellular protein kinase $C$ activation. It is partially dependent on extracellular calcium but appears to be unaffected by specific antagonists of membrane calcium channels or calmodulin. Epinephrine and beta-adrenergic agonists activate the cAMP-dependent system. Gastrin, CCK, and TPA (12-O-tetradecanoylphorbol-13-acetate, a phorbol ester that interacts directly with protein kinase C) activate the cAMP-independent pathway. It is of interest that CCK, on a molar basis, is a more potent stimulus of somatostatin release by these primary cultures than gastrin, although this greater potency does not correspond to great receptor affinity (61).

The inhibitory control of somatostatin release from primary cultures of enriched canine fundic $D$ cells is complex. Under standard conditions carbachol reduces both basal and stimulated somatostatin release (60). The focus for this action appears to be distal to "second messengers," since carbachol inhibits the response to a diverse set of stimuli including epinephrine, dibutyryl cAMP, forskolin, gastrin, or TPA. It is curious, however, that while carbachol induces cAMP production, concomitantly it induces an increase in the indices of membrane inositol phospholipid turnover (63-65). These 


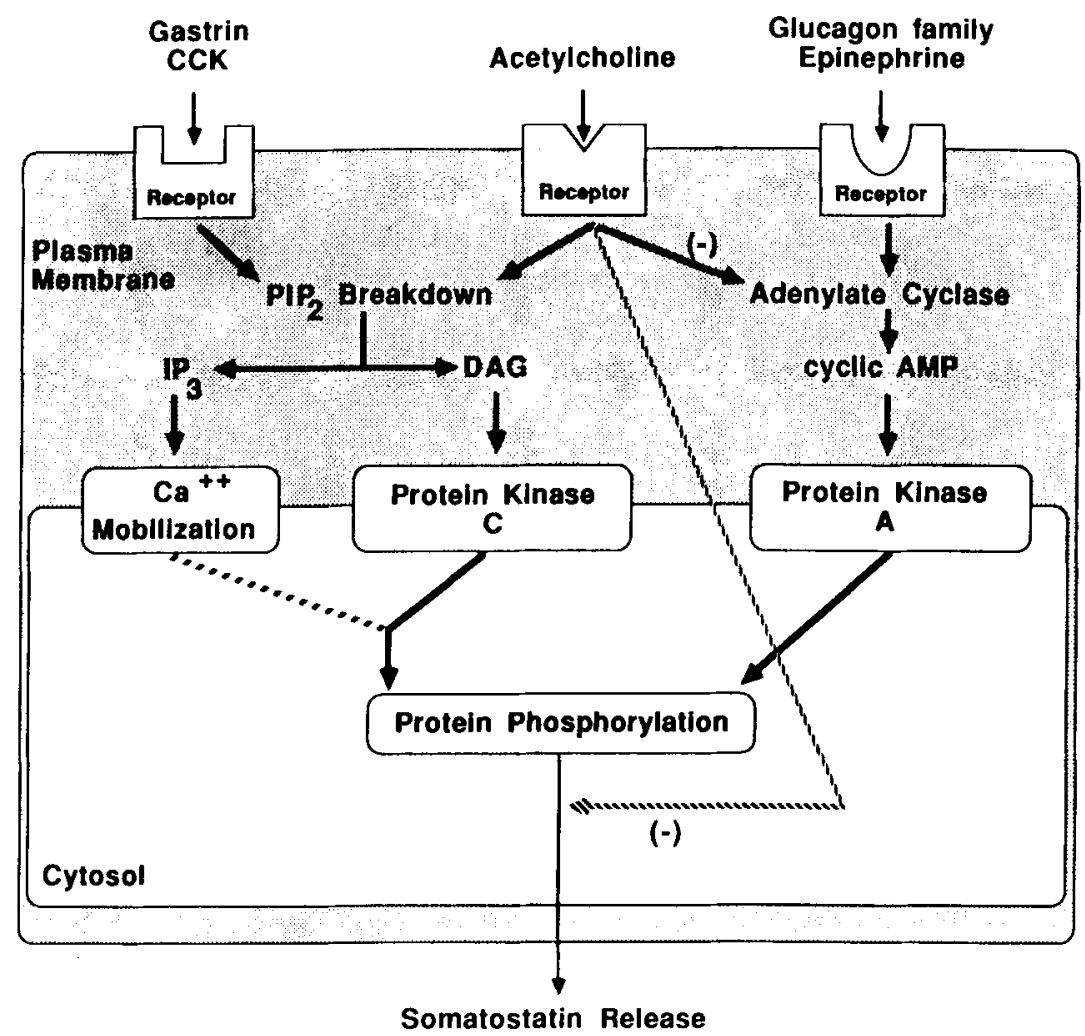

Fig 3. Intracellular mechanisms governing somatostatin release. CCK, cholecystokinin; DAG, diacylglycerol; $\mathrm{IP}_{3}$, inositol triphosphate; $\mathrm{PIP}_{2}$, phosphatidylinositol-4,5bisphosphate (from reference 66).

conflicting observations were reconciled after further studies in which primary cultures of fundic D cells were pretreated with pertussis toxin prior to administration of carbachol. Pertussis toxin binds inhibitory guanine nucleotide-binding proteins regulating adenylate cyclase activity. Following pertussis toxin pretreatment, carbachol had a stimulatory effect on basal somatostatin release and potentiated the stimulatory response to forskolin (64). Pretreatment with pertussis toxin abolished the carbachol-induced decrease in cAMP production, but the increase in membrane inositol phospholipid turnover was unchanged. Atropine reversed all effects of carbachol in pertussis-toxinpretreated D cells. These data suggest that in primary cultures of enriched canine fundic D cells carbachol interacts with a surface muscarinic receptor to have dual but contrary effects via separate intracellular mechanisms. First there is an inhibitory effect that is dependent in part on regulation of cAMP and that incorporates a pertussis-toxinsensitive guanine nucleotide-binding protein. This action is dominant and only when it is inhibited by pretreatment with pertussis toxin is a second, albeit stimulatory, action of carbachol revealed. The stimulatory effect is complex and probably is not solely dependent on increases in membrane phosphoinositide turnover since carbachol, in the presence of pertussis toxin, can potentiate the release of somatostatin induced by gastrin without further enhancing phosphoinositide turnover (65).

\section{ACTIONS OF SOMATOSTATIN IN THE GUT}

A recurring problem in estimating the actions of somatostatin has been an inability to distinguish between physiological and pharmacological effects. While it is relatively easy to mimic physiological plasma concentrations of somatostatin, appropriate doses to mimic paracrine concentrations are rarely, if ever, known. It is possible that grossly pharmacologic doses of somatostatin yield concentrations that are physiologic at the cell surface.

Table 2 lists the proposed functions of endogenous somatostatin in the gastrointestinal tract. These have recently been reviewed (66). The action 
Table 2. Biological Actions of Somatostatin In the Gut*

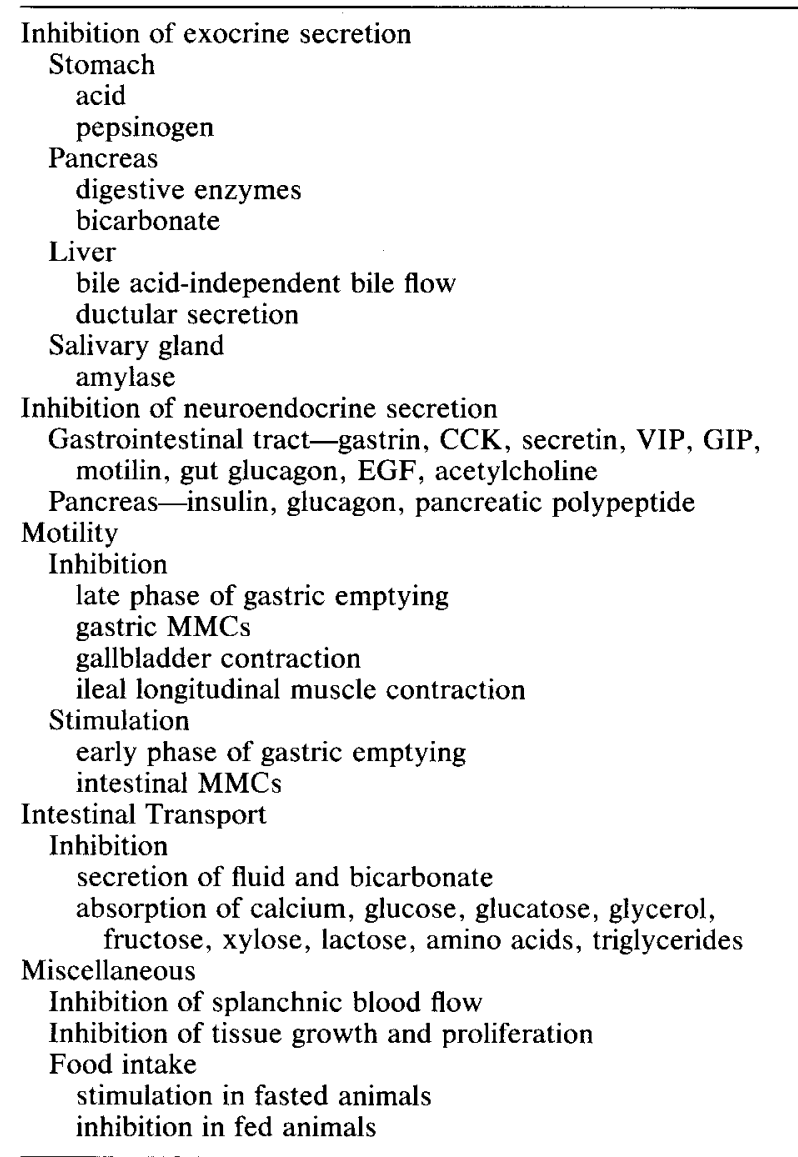

${ }^{*}$ From reference 66 .

of gut somatostatin that has received most attention is regulation of acid secretion. In both dogs (33) and man (45) in vivo it has been shown that a physiological increase in plasma somatostatin concentration, such as occurs postprandially, can result in reduction in acid secretion. This occurs without an alteration in plasma gastrin concentration. This suggests that somatostatin may circulate to act as an endocrine regulator of acid secretion. In the dog S14 is 10 times as potent an inhibitor of acid secretion as S28 (33). This became clear only after their different rates of metabolism were taken into consideration and their respective potencies examined as a function of incremental plasma concentration.
Recently Seal et al (67) have shown in rats with a gastric fistula that intravenous administration of a specific monoclonal antisomatostatin antibody can reverse the inhibitory action of intraduodenal infusion of oleic acid on meal-stimulated gastric acid secretion. This suggests that the acid inhibitory action of intraduodenal fat (so-called enterogastrone effect) is at least in part a consequence of the action of endogenous somatostatin. Whether this is an endocrine or paracrine phenomenon needs further study.

As noted earlier in this review, the morphology of gastric D cells with long cytoplasmic processes abutting onto local effector cells suggests a paracrine role for gastric somatostatin. Short et al (68) have reported that perfusion of an isolated rat stomach with antisomatostatin antibody enhanced acid secretion. Thus, locally released somatostatin may be acting as a restraint on acid secretion.

There are many mechanisms by which somatostatin might reduce acid secretion. As shown in Table 3, these include direct action on the parietal cell, inhibition of gastrin release, increased production of prostaglandins, and reduction in mucosal blood flow. It is most likely that somatostatin produces its effect on acid secretion by a combination of actions.

The advent of stable somatostatin analogs for use as radioligands has allowed demonstration of surface receptors for somatostatin on isolated enriched canine parietal cells in short-term culture (69). In this model, binding affinity closely parallels the inhibitory potency of the peptide. However, the equal potency of $\mathrm{S} 14$ and $\mathrm{S} 28$ observed in this model is in sharp contrast to the markedly greater potency of S14 compared to S28 in vivo. This suggests that indirect influences may be of great importance in determining the acid inhibitory action of circulating somatostatin. Although there are differences in their data, both Park et al (69) and Chew (70) have been able to demonstrate a direct effect of somatostatin on function in isolated parietal cells.

The influence of somatostatin, if any, on gastrin secretion is most likely to be paracrine since plasma concentrations of somatostatin sufficient to inhibit

Table 3. Mechanisms of Somatostatin-Induced Acid Inhibition*

\begin{tabular}{lllll}
\hline Receptor & \multicolumn{1}{c}{$?$} & ? & Gastrin cell & Parietal cell \\
Effects & $\downarrow$ Blood flow & $\uparrow$ Prostaglandin & $\downarrow$ Gastrin release & $\downarrow$ Gastrin/acetylcholine effect \\
\multirow{2}{*}{ Mechanism } & $\downarrow \mathrm{O}_{2}$ & $\downarrow$ Histamine effect & $\downarrow$ Stimulation & $\downarrow$ Stimulation \\
& $\downarrow$ Metabolic function & $\downarrow$ Protein kinase A & $\downarrow$ Protein kinase C & $\downarrow$ Postkinase activation action \\
\hline
\end{tabular}

*From reference 66. 
acid secretion completely had no effect on serum gastrin. The morphology of $\mathrm{D}$ cells in the antrum supports this mechanism of action. Much work has been directed at defining the exact interrelationship of gastrin and somatostatin. In many instances the secretion of the two peptides appears reciprocal, demonstrating a so-called functional linkage, but this is not invariable. Nonetheless, local regulation of gastrin by somatostatin appears probable.

\section{CELLULAR BASIS OF SOMATOSTATIN ACTION}

In order to consider the cellular mechanisms by which somatostatin exerts its actions, one must frequently extrapolate from studies in nongastrointestinal systems. These studies, as well as studies in cells of gastrointestinal origin, suggest that somatostatin may have many effects. Somatostatin has been shown to interfere with cAMP production in primary cultures of enriched parietal cells through inhibition of adenylate cyclase (69). This action (and some others described below) may require interaction with a membrane-associated guanine nucleotide regulatory protein. Somatostatin may also inhibit parietal cell function by interfering with a cAMP-related pathway at a point distal to cAMP production or through cAMP-independent mechanisms (69). In nongastrointestinal D cells it has been proposed that this pathway is also related to a membrane-associated pertussis-toxin-sensitive guanine nucleotide-regulating protein (71). There are conflicting data regarding the role of intracellular calcium fluxes in modulating the cAMP-independent pathway. Somatostatin may act through a more nonselective mechanism such as that proposed by Reyl and Lewin (72), who showed that the intracellular binding site for somatostatin in gastric mucosa may be a phosphoprotein phosphatase. It has been suggested that somatostatin alters membrane-related events, such as dephosphorylating membrane proteins (73), or alters the final exocytic process (74). By whatever mechanism somatostatin acts, its physiological importance as a regulator of many processes in the body is profound. The potential usefulness of an analog of this interesting hormone in therapy of a variety of human pathological conditions will soon be explored.

\section{ACKNOWLEDGMENTS}

We are grateful to Lori Ennis for typing this manuscript.

\section{REFERENCES}

1. Krulich L, Dharival APS, McCann SM: Stimulatory and inhibitory effects of purified hypothalamic extracts in growth hormone release from rat pituitary in vitro. Endocrinology 83:783-790, 1968

2. Brazeau P, Vale W, Burgus R, Ling N, Butcher M, Rivier J, Guillemin R: Hypothalamic polypeptide that inhibits the secretion of immunoreactive pituitary growth hormone. Science 179:77-79, 1973

3. Brazeau P, Epelbaum S, Tannenbaum G, Rorstad O, Martin $\mathrm{J}$ : Somatostatin: Isolation, characterization, distribution, and blood determination. Metabolism 27(Suppl 1):11331137,1978

4. Arimura A, Sato H, Coy DH, Schally AV: Radioimmunoassay for GH-release inhibiting hormone. Proc Soc Exp Biol Med 148:784-789, 1975

5. Arimura A, Sato H, Dupont A, Nishi N, Schally A: Somatostatin: Abundance of immunoreactive hormone in rat stomach and pancreas. Science 189:1007-1009, 1975

6. Schally AV, Dupont A, Arimura A, Redding TW, Nishi N, Linthicum GL, Schlesinger DH: Isolation and structure of somatostatin from porcine hypothalami. Biochemistry 15: $509-514,1976$

7. Noe B, Spiess J, Rivier J, Vale W: Isolation and characterization of somatostatin from anglerfish pancreatic islet. Endocrinology 105:1410-1414, 1979

8. Conlon JM: Isolation and structure of guinea pig gastric and pancreatic somatostatin. Life Sci 35:213-220, 1984

9. Andrews PC, Dixon JE: Isolation and structure of a peptide hormone predicted from a mRNA sequence and second somatostatin from the catfish pancreas. J Biol Chem 256: $8267-8270,1981$

10. Takami M, Reeve J, Hawke D, Shively J, Basinger S, Yamada T: Purification of somatostatin from frog brain: Coisolation with retinal somatostatin-like immunoreactivity. J Neurochem 45:1869-1874, 1985

11. Pradayrol L, Jornvall J, Mutt V, Ribet A: $N$-terminally extended somatostatin: The primary structure of somatostatin-28. FEBS Lett 109:55-58, 1980

12. Hobart P, Crawford R, Shen L, Pictet R, Rutter W: Cloning and sequence analysis of cDNAs encoding two distinct somatostatin precursors found in the endocrine pancreas of anglerfish. Nature 288:137-141, 1980

13. Minth C, Taylor W, Magazin M, Tavianini M, Collier K, Weith HL, Dixon, J: The structure of cloned DNA complementary to catfish pancreatic somatostatin-14 messenger RNA. J Biol Chem 257:10372-10377, 1982

14. Goodman RH, Jacobs JW, Dee PC, Habener JF: Somatostatin-28 encoded in a cloned cDNA obtained from a rat medullary thyroid carcinoma. J Biol Chem 257:1156-1159, 1982

15. Shen LP, Pictet R, Rutter W: Human somatostatin I: Sequence of the cDNA. Proc Natl Acad Sci USA 79:45754579,1982

16. Shen LP, Rutter W: Sequence of the human somatostatin I gene. Science 224:168-171, 1984 
17. Montminy MR, Goodman RH, Horovitch SJ, Habener JF: Primary structure of the gene encoding rat preprosomatostatin. Proc Natl Acad Sci USA 81:3337-3340, 1984

18. Tavianini MA, Hayes TE, Magazin MD, Minth CD, Dixon $\mathrm{JE}$ : Isolation, characterization, and DNA sequence of the rat somatostatin gene. J Biol Chem 259:11798-11803, 1984

19. Fujita T, Kobayashi S: The cells and hormones of the GEP endocrine system-the current of studies. In Gastroenteropancreatic Endocrine System. A Cell-Biological Approach. T Fujita (ed). Tokyo, Igaku Shoin 1973, pp 1-16

20. Kusumoto Y, Iwanaga T, Ito S, Fujita T: Juxtaposition of somatostatin cell and parietal cell in the dog stomach. Arch Histol Jpn 42:459-465, 1979

21. Larsson LI: Distribution and morphology of somatostatin cells. In Somatostatin. YC Patel, GS Tannebaum (eds). New York, Plenum, 1985, pp 383-402

22. Larsson LI, Goltermann N, Demagistris L, Rehfeld JF, Schwartz TW: Somatostatin cell processes as pathways for paracrine secretion. Science 205:1393-1395, 1979

23. Costa M, Patel Y, Furness JB, Arimura A: Evidence that some intrinsic neurons of the intestine contain somatostatin. Neurosci Lett 6:215-222, 1977

24. Vinik AI, Gaginella TS, O'Dorisio TM, Shapiro B, Wagner $\mathrm{L}$ : The distribution and characterization of somatostatin-like immunoreactivity in epithelial cells, submucosa, and muscle of the rat stomach and intestine. Endocrinology 19:19211926,1981

25. Baldissera FGA, Holst JJ, Jensen SL, Krarup T: Distribution and molecular forms of peptides containing somatostatin immunodeterminants in extracts from the entire gastrointestinal tract of man and pig. Biochim Biophys Acta 838:132-143, 1985

26. Chayvialle JA, Miyata M, Rayford PL, Thompson JC: Immunoreactive somatostatin and vasoactive intestinal peptide in the digestive tract of cats. Gastroenterology 79:837843,1980

27. Penman E, Wass JAH, Butler MG, Penny ES, Price J, Wu P, Rees LH: The distribution and characterization of immunoreactive somatostatin in human gastrointestinal tract. Regulatory Peptides 7:53-65, 1983

28. Trent DF, GC Weir: Heterogeneity of somatostatin-like peptides in rat brain, pancreas, and gastrointestinal tract. Endocrinology 108:2033-2037, 1981

29. Chayvialle JA, Rayford PL, Thompson JC: Radioimmunoassay study of hepatic clearance and disappearance half-time of somatostatin and vasoactive intestinal peptide in dogs. Gut 22:732-737, 1981

30. Patel YC, Wheatley T: In vivo and in vitro plasma disappearance and metabolism of somatostatin-28 and somatostatin- 14 in the rat. Endocrinology 112:220-225, 1983

31. Polonsky K, Jaspan J, Berelowitz M, Pugh W, Moossa A, Ling N: The in vivo metabolism of somatostatin 28: Possible relationship between diminished metabolism and enhanced biological action. Endocrinology 111:1698-1703, 1982

32. Schusdziarra V, Harris V, Unger RH: Half-life of somatostatin-like immunoreactivity in canine plasma. Endocrinology 104:109-110, 1979

33. Seal A, Yamada T, Debas H, Hollinshead J, Osadchey B, Aponte G, Walsh J: Somatostatin-14 and -28: Clearance and potency on gastric function in dogs. Am J Physiol (Gastrointest Liver Physiol 6) 243:G97-G102, 1982
34. Sheppard M, Shapiro B, Pimstone B, Kronheim S, Berelowitz M, Gregory M: Metabolic clearance and plasma halfdisappearance time of exogenous somatostatin in man. J Clin Endocrinol Metab 48:50-52, 1979

35. Vaysse N, Chayvialle JA, Pradayrol L, Esteve JP, Susini C, Lapuelle J, Descos F, Ribet A: Somatostatin 28: Comparison with somatostatin 14 for plasma kinetics and low-dose effects on the exocrine pancreas in dogs. Gastroenterology $81: 700-706,1981$

36. Conlon JM, Whittaker J, Hammond V, Alberti K: Metabolism of somatostatin and its analogues by the liver. Biochim Biophys Acta 677:234-242, 1981

37. Sacks H, Terry LC: Clearance of immunoreactive somatostatin by perfused rat liver. J Clin Invest 67:419-429, 1981

38. Taborsky G, Ensinck $\mathbf{J}$ : Extraction of somatostatin by the pancreas. Endocrinology 112:303-307, 1983

39. Ruggere MD, Patel Y: Somatostatin metabolism by the isolated rat lung. Endocrinology 117:1870-1873, 1985

40. Polonsky KS, Jaspan JB, Berelowitz M, Emmanouel DS, Dhorajiwala J: Hepatic and renal metabolism of somatostatin-like immunoreactivity. J Clin Invest 68:1149-1157, 1981

41. Pardridge WM, Eisenberg J, Yamada T: Rapid sequestration and degradation of somatostatin analogues by isolated brain microvessels. J Neurochem 44:1178-1184, 1985

42. Weber M, Cole T, Conlon JM: Specific binding and degradation of somatostatin by membrane vesicles from pig gut. Am J Physiol (Gastrointest Liver Physiol 13) 250:G679$\mathrm{G} 685,1986$

43. Chiayvialle JA, Miyata M, Rayford PL, Thompson JC: Effects of test meal, intragastric nutrients, and intraduodenal bile on plasma concentrations of immunoreactive somatostatin and vasoactive intestinal peptide in dogs. Gastroenterology 79:844-852, 1980

44. Colturi TM, Unger RJ, Feldman M: Role of circulation somatostatin in regulation of gastric acid secretion, gastrin release, and islet cell function. Studies in healthy subjects and duodenal ulcer patients. J Clin Invest 74:417-423, 1984

45. Penman E, Wass JAH, Medbak S, Morgan L, Lewis JM, Besser GM, Rees LH: Response of circulating immunoreactive somatostatin to nutritional stimuli in normal subjects. Gastroenterology 81:692-699, 1981

46. Polonsky KS, Shoelson SE, Docherty HM: Plasma somatostatin-28 increases in response to feeding in man. $\mathrm{J}$ Clin Invest 71:1514-1518, 1983

47. Schusdziarra V, Harris V, Conlon JM, Arimura A, Unger RH: Pancreatic and gastric somatostatin release in response to intragastric and intraduodenal nutrients and $\mathrm{HCl}$ in the dog. J Clin Invest 62:508-518, 1978

48. Taborsky GJ, Ensinck JW: Contribution of the pancreas to circulating somatostatin-like immunoreactivity in the normal dog. J Clin Invest 73:216-233, 1984

49. Gustavsson S, Lundquist G: Participation of antral somatostatin in the local regulation of gastrin release. Acta Endocrinol 88:339-346, 1978

50. Holst JJ, Jensen SL, Knuhtsen S, Nielsen OV, Rehfeld JF: Effect of vagus, gastric inhibitory polypeptide, and $\mathrm{HCl}$ on gastrin and somatostatin release from perfused pig antrum. Am J Physiol (Gastrointest Liver Physiol 7) 244:G515-G522, 1983 
51. Lucey MR, Wass JAH, Fairclough PD, O'Hare M, Kwasowski P, Penman E, Webb J, Rees LH: Does gastric acid release plasma somatostatin in man? Gut 25:1217-1220, 1984

52. Guzman S, Chayvialle JA, Banks WA, Rayford PL, Thompson JC: Effects of vagal stimulation on pancreatic secretion and on blood levels of gastrin, cholecystokinin, secretion, vasoactive intestinal peptide, and somatostatin. Surgery 86 : 329-336, 1979

53. Lucey MR, Wass JAH, Fairclough P, Webb J, Webb S, Medbak S, Rees LH: Autonomic regulation of postprandial plasma somatostatin, gastrin and insulin. Gut 26:683-688, 1985

54. Uvnas-Wallensten $\mathrm{K}$, Efendic S, Roovete A, Johansson C: Decreased release of somatostatin into the portal vein following electrical vagal stimulation in the cat. Acta Physiol Scand 109:393-398, 1980

55. Martindale R, Kauffman GL, Levin S, Walsh JH, Yamada $\mathrm{T}$ : Differential regulation of gastrin and somatostatin secretion from isolated perfused rat stomachs. Gastroenterology 93:240-244, 1982

56. McIntosh C, Pederson RA, Koop H, Brown JC: Gastric inhibitory polypeptide stimulated secretion of somatostatinlike immunoreactivity from the stomach: Inhibition by acetylcholine or vagal stimulation. Can J Physiol Pharmacol 59: 468-472, 1980

57. Saffouri B, Weir GC, Bitar KN, Makhlouf GM: Gastrin and somatostatin secretion by perfused rat stomach: Functional Linkage of antral peptides. Am J Physiol (Gastrointest Liver Physiol 1) 238:G495-G501, 1980

58. Sue R, Toomey ML, Todisco A, Soll AH, Yamada T: Pirenzepine-sensitive muscarinic receptors regulate gastric somatostatin and gastrin. Am J Physiol (Gastrointest Liver Physiol 11) 248:G184-G187, 1985

59. Soll AH, Yamada T, Park J, Thomas LP: Release of somatostatin-like immunoreactivity from canine fundic mucosal cells in primary culture. Am J Physiol (Gastrointest Liver Physiol 10) 247:G558-G566, 1984

60. Yamada T, Soll AH, Park J, Elashoff J: Autonomic regulation of somatostatin release: Studies with primary cultures of canine fundic mucosal cells. Am J Physiol (Gastrointest Liver Physiol 10) 247:G567-G573, 1984

61. Soll AH, Amirian DA, Park J, Elashoff JD, Yamada T: Cholecystokinin potently releases somatostatin from canine fundic mucosal cells in short-term culture. Am J Physiol (Gastrointest Liver Physiol 11) 248:G569-G573, 1985
62. Sugano K, Park J, Soll A, Yamada T: Phorbol esters stimulate somatostatin release from cultured cells. Am J Physiol (Gastrointest Liver Physiol 13) 250:G686-G690, 1986

63. Chiba T, Sugano K, Park J, Yamada T: Potential mediation of somatostatin secretion from canine fundic D-cells by protein kinase C. Am J Physiol 253:G52-G57, 1987

64. Chiba T, Raffoul K, Yamada T: Divergent stimulatory and inhibitory actions of carbamoylcholine on gastric D-cells. J Biol Chem 262:8467-8469, 1987

65. Chiba T, Yamada T: Mechanisms for the stimulatory and inhibitory effects of carbamoylcholine on canine gastric D-cells. Biochem Biophys Res Commun 147:140-144, 1987

66. Yamada T, Chiba T: Somatostatin. In Handbook of Physiology, Section on Neuroendocrinology of the Gut. G Makhlouf (ed). Bethesda, Maryland, 1988 (in press)

67. Seal AM, Meloche RM, Liu WE, Buchan AMJ, Brown JC: Effects of monoclonal antibodies to somatostatin on somatostatin-induced and intestinal fat-induced inhibition of gastric acid secretion in the rat. Gastroenterology 92:1187-1192, 1987

68. Short GM, Doyle JW, Wolfe MM: Effect of antibodies to somatostatin on acid secretion and gastrin release by the isolated perfused rat stomach. Gastroenterology 88:984-988, 1985

69. Park J, Chiba T, Yamada T: Mechanisms for direct inhibition of canine gastric parietal cells by somatostatin. J Biol Chem 262:14190-14196, 1987

70. Chew CS: Inhibitory action of somatostatin on isolated gastric glands and parietal cells. Am J Physiol (Gastrointest Liver Physiol 8) 245:G221-G229, 1983

71. Yajima Y, Akita Y, Saito T: Pertussis toxin blocks the inhibitory effects of somatostatin on cAMP-dependent vasoactive intestinal peptide and CAMP-independent thyrotropin releasing hormone-stimulated prolactin secretion of $\mathrm{GH}_{3}$ cells. J Biol Chem 261:2684-2689, 1986

72. Reyl FJ, Lewin MJM: Intracellular receptor for somatostatin in gastric mucosal cells: Decomposition and reconstitution of somatostatin-stimulated phosphoprotein phosphatases. Proc Natl Acad Sci USA 79:978-982, 1982

73. Hierowski MT, Leibow C, Sapin K, Schally AV: Stimulation by somatostatin of dephosphorylation of membrane proteins in pancreatic cancer MIA PaCa-2 cell line. FEBS Lett 179:252-256, 1985

74. Green R, Shields D: Somatostatin discriminates between the intracellular pathways of secretory and membrane proteins. J Cell Biol 99:97-104, 1984 